\title{
Retraction Note to: Biological and Biochemical Potential of Sea Snake Venom and Characterization of Phospholipase $\mathbf{A}_{2}$ and Anticoagulation Activity
}

\author{
Palani Damotharan ${ }^{1,3}$ - Anguchamy Veeruraj ${ }^{1,2} \cdot$ Muthuvel Arumugam $^{1}$ • \\ Thangavel Balasubramanian ${ }^{1}$
}

Published online: 21 December 2020

(C) Association of Clinical Biochemists of India 2020

Retraction Note to: Ind J Clin Biochem (Jan-Mar 2016) 31(1):57-67 https://doi.org/10.1007/s12291-015-0500-6

The Editor-in-Chief has retracted this article [1] because figures 1 and 2, and table 2, as well as parts of the text, were duplicated from a previously published article by Damotharan et al. [2]. Additionally, figures 3 and 4 appear to be very similar to figures $3 a$ and $3 b$ in [2], but these figures in [2] appear to have an additional band. In additional, figure 5 appears to be similar to Figure 1 in [3]. The data reported in this article are therefore unreliable. The authors have not responded to correspondence regarding this retraction.

\section{References}

1. Damotharan P, Veeruraj A, Arumugam M, et al. Biological and biochemical potential of sea snake venom and characterization of phospholipase $\mathrm{A}_{2}$ and anticoagulation activity. Ind $\mathrm{J}$ Clin Biochem. 2016;31:57-67. https://doi.org/10.1007/s12291-0150500-6.

2. Damotharan P, Veeruraj A, Arumugam M, Balasubramanian T. Isolation and characterization of biologically active venom protein from sea snake Enhydrina schistosa. J Biochem Mol Toxicol. 2015;29:140-7. https://doi.org/10.1002/jbt.21678.

3. Rajesh Kumar K, Vennila R, Kanchana S, et al. Fibrinogenolytic and anticoagulant activities in the tissue covering the stingers of marine stingrays Dasyatis sephen and Aetobatis narinari. J Thromb Thrombolysis. 2011;31:464-71. https://doi.org/10. 1007/s11239-010-0537-6.

Publisher's Note Springer Nature remains neutral with regard to jurisdictional claims in published maps and institutional affiliations.

The original article can be found online at https:// doi.org/10.1007/s12291-015-0500-6.

\section{Palani Damotharan}

damotharanp@gmail.com

$\triangle$ Anguchamy Veeruraj anguveeruraj@gmail.com

1 Faculty of Marine Sciences, Centre of Advanced Study in Marine Biology, Annamalai University,

Parangipettai 608 502, India

2 Centre for Ocean Research, (SU-NIOT Joint Initiative Research Centre), Sathyabama University, Rajiv Gandhi Salai, Chennai 600 119, India

3 Marine Biotechnology, National Institute of Ocean Technology (NIOT), Ministry of Marine Science Govt. of India, Chennai 600 100, India 